\title{
Renal cell carcinoma with osseous metaplasia: A case report and literature review
}

\author{
Heather Maioli ${ }^{1}$, Meenal Sharma ${ }^{1}$, Genevieve M Crane ${ }^{1}$, Guan Wu ${ }^{1,2}$ and Hiroshi Miyamoto ${ }^{1-3 *}$ \\ ${ }^{1}$ Department of Pathology \& Laboratory Medicine, University of Rochester Medical Center, USA \\ ${ }^{2}$ Department of Urology, University of Rochester Medical Center, USA \\ ${ }^{3}$ Department of Oncology, University of Rochester Medical Center, USA
}

\begin{abstract}
Ossification is rarely seen in renal cell carcinomas. We report a case of a 63-year-old man who was found to have bilateral renal masses on positron emission tomography-computed tomography. One of partial nephrectomy specimens histologically showed a papillary renal cell carcinoma containing bone trabeculae. We also review renal cell carcinoma cases with osseous metaplasia reported in the literature.
\end{abstract}

\section{Background}

Calcifications caused by a plethora of etiologies are found often radiologically in various subtypes of renal cell carcinomas (RCCs) [1]. Sarcomatoid differentiation is also seen in a subset of RCCs and is generally associated with poor patient outcomes. By contrast, metaplastic bone formation with or without bone marrow elements in RCC is extremely rare yet has been reported predominantly in clear cell [2-12] and chromophobe [13-16] subtypes. We here present a case of papillary RCC with osseous metaplasia along with a review of the literature on this unusual condition.

\section{Case report}

A 63-year-old Caucasian man with a history of squamous cell carcinoma of the tongue with regional lymph node metastasis, who was status-post chemotherapy and radiotherapy, was found to have bilateral renal masses on positron emission tomography (PET)computed tomography (CT) (Figure 1). Patient did not have any urinary symptoms at the time, including gross hematuria and flank pain, and was referred to a urology clinic for management. No family history of RCC was noted. A follow-up CT scan of the abdomen/pelvis showed an $8-\mathrm{cm}$ right renal mass located in the lower pole with dense calcification/ossification (Figure 2) and a 5-cm left renal mass located in the lateral border. Both masses were enhancing, raising concern for RCC. In addition, numerous renal cysts and smaller masses were documented bilaterally. Based on these findings, the patient underwent a right partial nephrectomy.

During the surgery, intraoperative ultrasound was utilized to delineate multiple cystic-looking lesions from concerning tumors. Once the more exophytic lesions were located, the more lateral tumors were excised with 2-5 mm margins. One of three partial nephrectomy specimens received for examination grossly showed an $8.5-\mathrm{cm}$ tanorange to red-brown friable mass that was well encapsulated and contained central areas of calcification. Histologic examination of the tumor revealed a papillary RCC, WHO/ISUP grade 3, with focal areas of bone formation containing adipose tissue without bone marrow elements (Figure 3). This tumor was staged as pT2aNX. The other two partial nephrectomy specimens histologically showed papillary
RCCs $(1.7 \mathrm{~cm}$ and $1.6 \mathrm{~cm}$ in their greatest dimensions, respectively) without calcifications or bone formation. All surgical margins were negative for tumor.

The patient underwent partial nephrectomies for left renal masses 2 months after the initial surgery. Two of the specimens again histologically showed organ-confined papillary RCCs $(5.3 \mathrm{~cm}$ and 2.6 $\mathrm{cm}$ in their greatest dimensions, respectively) without ossification, in addition to atypical cysts in other two specimens. He is free from disease 8 months after right partial nephrectomies and is scheduled to undergo surveillance imaging.

\section{Discussion}

Calcification found in a variety of tissues refers to the deposition of hydroxyapatite deposition within the tissue and can be seen in
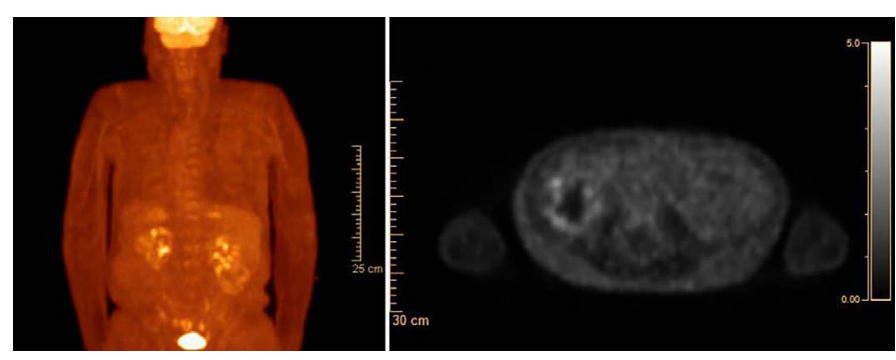

Figure 1. PET CT revealed a right renal mass with hypermetabolism up to SUV 3.3 suspicious for RCC.

Correspondence to: Hiroshi Miyamoto, MD, PhD, Department of Pathology \& Laboratory Medicine, University of Rochester Medical Center, 601 Elmwood Avenue, Box 626, Rochester, NY 14642, USA, Tel: +1(585)2758748, E-mail: hiroshi_miyamoto@urmc.rochester.edu

Key words: renal neoplasm, papillary renal cell carcinoma, ossification, bone marrow elements

Received: October 08, 2017; Accepted: October 27, 2017; Published: October 30,2017 


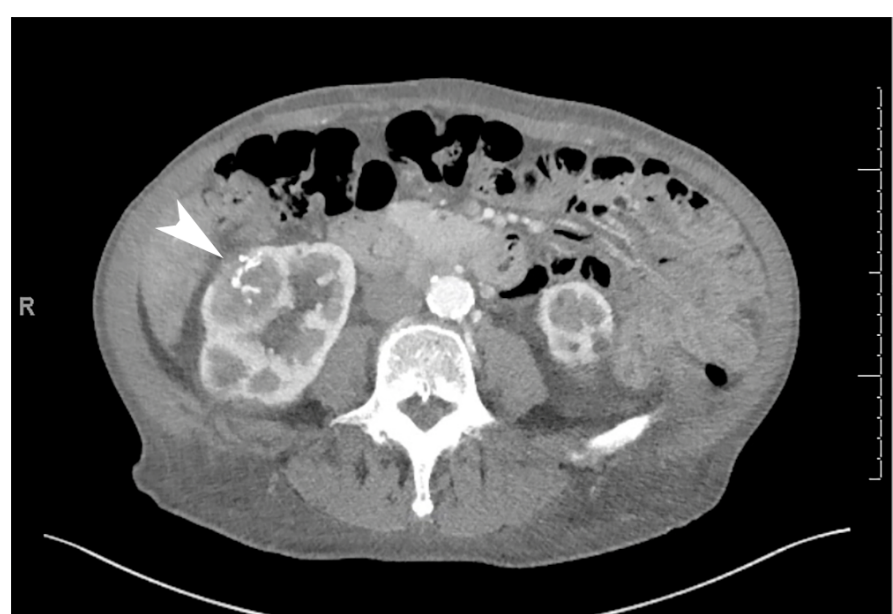

Figure 2. Abdominal $\mathrm{CT}$ scan revealed an 8 -cm solid-appearing mass arising from the lower pole of the right kidney. It contains multiple coarse calcifications (arrowhead).

association with both benign and malignant processes. Osseous metaplasia, however, is a rarer phenomenon. It refers to the presence of mature or immature bone in tissue where bone is not commonly found, while no clear mechanism for ossification has identified. An example of this includes mature bone formation within the endometrial tissue [17]. However, this type of metaplasia is not restricted to the endometrium. As seen primarily in case reports, osseous metaplasia can be present in a number of both benign and malignant lesions in, for instance, the spinal cord and breast, as well as various polyps [18-22], while there appear to be no precise incidence data for osseous metaplasia associated with different types of neoplasms or in different sites.

Osseous metaplasia has also been reported in patients with renal diseases, including less than 20 cases of the major subtypes of RCC [2-16,23-26]. Table 1 summarizes clinicopathologic features of these cases, including the present case, reported in case studies of osseous metaplasia associated with RCC. These patients included 8 males and 11 females with a mean/median age of 52.4/48 years (one case with no information), in contrast to a known male predilection towards RCC and its peak incidence during the sixth and seventh decade of life [27]. Osseous metaplasia has been associated mostly with clear cell RCC $(n=11)$ or chromophobe RCC $(n=4)$, and only one case of papillary $\mathrm{RCC}$ has been reported. Accordingly, ours is the second reported case of papillary RCC with associated osseous metaplasia. Histopathologically, these RCCs were organ-confined (pT1 or pT2: $n=9)$ or pT3a $(n=3)$ diseases (unknown: $\mathrm{n}=8$ ) with a mean/median tumor size of $8.5 / 6.5 \mathrm{~cm}$. In addition, most of the tumors (10 of 12) exhibited Fuhrman grade of 1 or 2 . No lymph node or distant metastasis has been reported in these cases. Meanwhile, bone marrow elements have been identified within bony formation in 4 of 19 cases.

Molecular mechanisms of heterotopic ossification that often occurs following traumatic injury or invasive surgery have been extensively studied, and bone morphogenetic proteins (BMPs) are shown to involve its steps as the primary inducer [28,29]. By contrast, little is known about the histogenesis of intratumoral osseous metaplasia. Hypotheses include osteoblast metaplasia of tumor cells and metaplastic changes of pluripotent stromal cells to osteoblasts by factors secreted by tumor cells [30]. In RCC, osseous metaplasia was suggested to represent secondary changes to ischemia, hemorrhage, necrosis, fibrosis, and/or hyalinization [2,25]. The involvement of BMP2 in ossification of RCC has also been documented [31,32].

The prognostic consequences of osseous metaplasia remain poorly understood. However, most of RCC cases were low-grade organconfined diseases. Moreover, none has been found to have metastasis at the time of nephrectomy or subsequent disease recurrence or progression. These findings suggest that RCC in most of cases where osseous metaplasia was reported was found during the early stages of disease. Thus, osseous metaplasia may serve as a prognosticator and implies favorable outcomes in RCC patients. It is also important to distinguish osseous metaplasia from sarcomatoid carcinoma with bone formation (e.g. osteosarcomatous differentiation) that is generally associated with poor prognosis.

In conclusion, papillary RCC associated with osseous metaplasia is a very rare occurrence. It may be worthwhile to further investigate underlying mechanisms for osseous metaplasia within RCC as well as its prognostic significance.

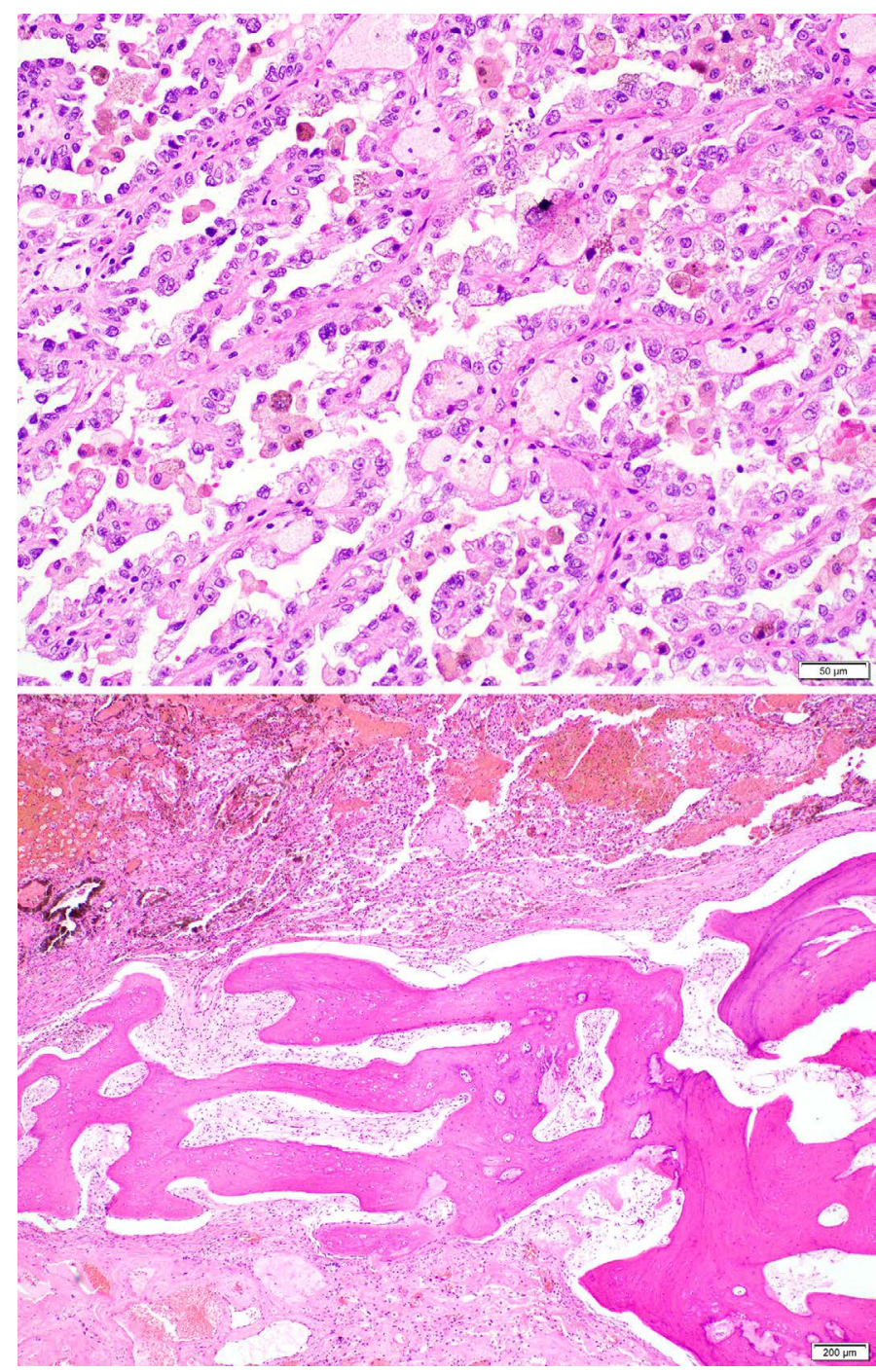

Figure 3. Hematoxylin-eosin stained sections showed papillary RCC (upper; magnification: $200 x$ ) and adjacent lamellar bone forming a trabecula (lower; magnification: 40x). 
Table 1. Summary of literature review.

\begin{tabular}{|c|c|c|c|c|c|c|c|c|c|c|}
\hline Author, yr [Reference] & $\begin{array}{l}\text { Age (yr) / } \\
\text { Sex }\end{array}$ & Laterality & $\begin{array}{l}\text { Radical vs. partial } \\
\text { nephrectomy }\end{array}$ & $\begin{array}{l}\text { Histologic } \\
\text { subtype }\end{array}$ & $\begin{array}{l}\text { Tumor } \\
\text { size (cm) }\end{array}$ & $\begin{array}{l}\text { Tumor grade } \\
\text { (Fuhrman) }\end{array}$ & $\begin{array}{l}\text { Tumor } \\
\text { stage* }\end{array}$ & $\begin{array}{l}\text { Nodal } \\
\text { status* }\end{array}$ & $\begin{array}{l}\text { Bone } \\
\text { marrow } \\
\text { elements }\end{array}$ & Prognosis \\
\hline Cribbs et al. 1999 [2] & $57 / F$ & Right & Radical & CCRCC & 18 & G2 & pT3a & N/A & Yes & N/A \\
\hline Yokozaki et al. 2000 [13] & $60 / \mathrm{M}$ & Left & Partial & ChRCC & 2.7 & N/A & N/A & N/A & No & NED, 2 years \\
\hline Bielsa et al. 2001 [3] & $74 / F$ & Bilateral & $\begin{array}{l}\text { Partial (bilateral) } \\
\rightarrow \text { Radical (left) }\end{array}$ & CCRCC & N/A & G1 & N/A & N/A & No & NED, 2 years \\
\hline Bloom et al.,2003 [4] & $25 / \mathrm{F}$ & Right & Radical & CCRCC & 10.5 & G2 & pT3a & pNX & No & N/A \\
\hline Kuroda et al. 2005 [14] & $74 / F$ & Left & Radical & ChRCC & 3.6 & N/A & N/A & N/A & Yes & N/A \\
\hline Kefeli et al.,2007 [15] & $27 / F$ & Right & Radical & ChRCC & 6.5 & N/A & $\mathrm{pT} 1 \mathrm{~b}$ & N/A & Yes & NED, 1 year \\
\hline Murugan et al. 2008 [5] & $35 / \mathrm{F}$ & Right & Radical & CCRCC & 12.5 & $\mathrm{G} 2$ & $\mathrm{pT} 2 \mathrm{~b}$ & N/A & No & N/A \\
\hline Puppa et al. 2008 [6] & $46 / \mathrm{M}$ & Left & Radical & CCRCC & 1.0 & G1 & pT1a & N/A & No & N/A \\
\hline Richmond et al. 2010 [7] & $61 / F$ & Left & Radical & CCRCC & N/A & G2 & pT2 & N/A & No & N/A \\
\hline Hartman et al. 2011 [8] & $48 / F$ & $\begin{array}{l}\text { Unilateral, } \\
\text { laterality } \\
\text { unknown }\end{array}$ & Partial & CCRCC & N/A & N/A & N/A & N/A & No & N/A \\
\hline Hussain et al. 2012 [23] & N/A & N/A & N/A & MTSCC & N/A & G2 & N/A & N/A & N/A & N/A \\
\hline Leung et al. 2012 [24] & $52 / F$ & Right & Radical & PRCC & N/A & N/A & N/A & N/A & No & NED, 2 years \\
\hline Ozkani et al. 2012 [9] & $68 / \mathrm{M}$ & Left & Radical & CCRCC & 8.5 & N/A & pT2a & N/A & Yes & NED, 18 months \\
\hline Tanaka et al. 2013 [16] & 77 / F & Right & Radical & ChRCC & 3.0 & N/A & pT1a & N/A & No & NED, 12 months \\
\hline Asghar et al. 2015 [25] & $47 / \mathrm{M}$ & Bilateral & Radical (left only) & MTSCC & 28.8 & G3 & pT3a & $\mathrm{pNX}$ & No & NED, 3 months \\
\hline Agarwal et al. 2015 [10] & $39 / \mathrm{M}$ & Left & Radical & CCRCC & 4.0 & G2 & pT1a & N/A & No & $\begin{array}{l}\text { NED, duration } \\
\text { unknown }\end{array}$ \\
\hline Yan et al. 2015 [26] & $48 / \mathrm{M}$ & $\begin{array}{l}\text { Unilateral, } \\
\text { laterality } \\
\text { unknown }\end{array}$ & Radical & CPRCC & 3.0 & G1 & pT1a & N/A & No & NED, 14 months \\
\hline Lai et al. 2017 [11] & 47 / M & Right & Radical & CCRCC & N/A & G1 & N/A & N/A & No & N/A \\
\hline Pan et al. 2017 [12] & $48 / F$ & Right & Partial & CCRCC & N/A & N/A & N/A & N/A & No & NED, 1 year \\
\hline Present case & $63 / \mathrm{M}$ & $\begin{array}{l}\text { Bilateral (right } \\
\text { only) }\end{array}$ & Partial (right) & PRCC & 8.5 & WHO/ISUP G3 & pT2a & pNX & No & NED, 8 months \\
\hline
\end{tabular}

CCRCC: Clear Cell Renal Cell Carcinoma, N/A: Not Available or Not Applicable, ChRCC: Chromophobe Renal Cell Carcinoma, MTSCC: Mucinous Tubular And Spindle Cell Carcinoma, PRCC: Papillary Renal Cell Carcinoma, CPRCC: Clear Cell Papillary Renal Cell Carcinoma, NED: No Evidence of Disease.

*We staged tumors according to the AJCC $7^{\text {th }}$ edition cancer staging manual (2010).

\section{References}

1. Prasad SR, Humphrey PA, Catena JR, Narra VR, Srigley JR, et al. (2006) Common and uncommon histologic subtypes of renal cell carcinoma: imaging spectrum with pathologic correlation. Radiographics 26: 1795-1806. [Crossref]

2. Cribbs RK, Ishaq M, Arnold M, O’Brien J, Lamb J, et al. (1999) Renal cell carcinoma with massive osseous metaplasia and bone marrow elements. Ann Diagn Pathol 3: 294 299. [Crossref]

3. Bielsa O, Lloreta J, Arango O, Serrano S, Gelabert-Mas A (2001) Bone metaplasia in a case of bilateral renal cell carcinoma. Urol Int 66: 55-56. [Crossref]

4. Bloom TL, Gray Sears CL, Williams TR, Linfesty RL, Amling CL (2003) Multilocular cystic renal cell carcinoma with osseous metaplasia in a 25 -year-old woman. Urology 61: 462. [Crossref]

5. Murugan P, Basu D, Manikandan R, Dorairajan LN, Kumar S (2008) Osseous metaplasia in renal cell carcinoma: report of a rare case. Indian J Pathol Microbiol 51: 399-401. [Crossref]

6. Puppa G, Gervasio A, Yorukoglu K, Colombari R, De Marchi F, et al. (2008) Huge renal cyst with parietal renal cell carcinoma, osseous metaplasia and a papillary adenoma: a case report with unique clinicopathological features and literature review. Virchows Arch 452: 325-330. [Crossref]

7. Richmond L, Atri M, Sherman C, Sharir S (2010) Renal cell carcinoma containing macroscopic fat on CT mimics an angiomyolipoma due to bone metaplasia without macroscopic calcification. Br J Radiol 83: e179-e181. [Crossref]

8. Hartman RJ, Helfand BT, Dalton DP (2011) Clear cell renal cell carcinoma with osseous metaplasia: a case report. Can J Urol 18: 5564-5567. [Crossref]

9. Ozkanli S, Yildirim A, Zemheri E, Keskin SK, Basok EK (2012) Osseous metaplasia and bone marrow elements in a case of renal cell carcinoma. Case Rep Urol 2012. 649257. [Crossref]

10. Agarwal S, Bohara S, Jha R, Khurana N, Agarwal PN (2015) Clear cell renal cell carcinoma with osseous metaplasia: Rare case report. J Cancer Res Ther 11: 1039. [Crossref]
11. Lai BM, Ka SY, Kan WK, Lam MW, Lee TF, et al. (2017) Case 237: Renal cell carcinoma with osseous metaplasia. Radiology 282: 293-298. [Crossref]

12. Pan H, Wu D, Wang H, Pan Y, Zhang T, et al. (2017) Clear cell renal cell carcinoma with extensive osseous metaplasia: Report of a rare case. Urology 105: e3-3e5. [Crossref]

13. Yokozaki H, Ukai R, Kawashita E, Ikeda H, Kuniyasu H, et al. (2000) Chromophobe renal cell carcinoma with osseous metaplasia: a case report. Jpn J Clin Oncol 30: 101104. [Crossref]

14. Kuroda N, Iiyama T, Moriki T, Shuin T, Enzan H (2005) Chromophobe renal cell carcinoma with focal papillary configuration, nuclear basaloid arrangement and stromal osseous metaplasia containing fatty bone marrow element. Histopathology 46: 712713. [Crossref]

15. Kefeli M, Yildiz L, Aydin O, Kandemir B, Faik Yilmaz A (2007) Chromophobe renal cell carcinoma with osseous metaplasia containing fatty bone marrow element: a case report. Pathol Res Pract 203: 749-752. [Crossref]

16. Tanaka Y, Koie T, Hatakeyama S, Hashimoto Y, Ohyama C1 (2013) Chromophobe renal cell carcinoma with concomitant sarcomatoid transformation and osseous metaplasia: a case report. BMC Urol 13: 72. [Crossref]

17. Khan SN, Modi M, Hoyos LR, Imudia AN, Awonuga AO (2016) Bone in the endometrium: A review. Int J Fertil Steril 10: 154-161. [Crossref]

18. Zapata E, Castiella A, Zubiaurre L, Agirre A, Rodriguez J (2012) Osseous metaplasia in a gastric adenomatous polyp. Endoscopy 44 Suppl 2 UCTN: E81. [Crossref]

19. Yilmaz M, Ibrahimov M, Kilic E, Ozturk O (2012) Heterotopic bone formation (osseous metaplasia) in nasal polyps. J Craniofac Surg 23: 620. [Crossref]

20. Promsopa C (2016) Septochoanal polyp with osseous metaplasia: a case report. J Med Case Rep 10: 149. [Crossref]

21. Saad ES, Milley KM, Al-Khan AA, Nimmo JS, Bacci B, et al. (2017) Canine mixed mammary tumour as a model for human breast cancer with osseous metaplasia. J Comp Pathol 156: 352-365. [Crossref] 
22. Prakash A, Mishra S, Tyagi R, Attri PC, Bhatnagar A, et al. (2017) Thoracic psammomatous spinal meningioma with osseous metaplasia: A very rare case report. Asian J Neurosurg 12: 270-272. [Crossref]

23. Hussain M, Ud Din N, Azam M, Loya A (2012) Mucinous tubular and spindle cell carcinoma of kidney: A clinicopathologic study of six cases. Indian J Pathol Microbiol 55: 439-442. [Crossref]

24. Leung C, Trainer V, Short E, Venkatanarasimha N (2012) A case of ossifying papillary renal cell carcinoma. Urology 80: e11-12. [Crossref]

25. Asghar AM, Uhlman MA, Dahmoush L, Deorah S (2015) Osseous metaplasia in mucinous tubular and spindle cell carcinoma of the kidney: A case of massive, bilateral tumors. Case Rep Urol 2015: 465450. [Crossref]

26. Yan WX, Cao WR, Zhao J, Zhang W, Wang XL, et al. (2015) Clear cell papillary renal cell carcinoma: a clinicopathologic analysis of 6 cases. Int J Clin Exp Pathol 8: 4595 4599. [Crossref]
27. Cohen HT, McGovern FJ (2005) Renal-cell carcinoma. N Engl J Med 353: 2477-2490 [Crossref]

28. Shi ST, de Gorter DJJ, Hoogaars WMH, 't Hoen PAC, ten Dijke P (2013) Overactive bone morphogenetic protein signaling in heterotopic ossification and Duchenne muscular dystrophy. Cell Mol Life Sci 70: 407-423. [Crossref]

29. Ramirez DM, Ramirez MR, Reginato AM, Medici D (2014) Molecular and cellular mechanisms of heterotopic ossification. Histol Histopathol 29: 1281-1285. [Crossref]

30. Huang RS, Brown RE, Buryanek J (2014) Heterotopic ossification in metastatic colorectal carcinoma: case report with morphoproteomic insights into the histogenesis. Ann Clin Lab Sci 44: 99-103. [Crossref]

31. Yamasaki M, Nomura T, Mimata H, Nomura Y (2004) Involvement of bone morphogenetic protein 2 in ossification of renal cell carcinoma. J Urol 172: 475-476. [Crossref]

32. Wang L, Park P, La Marca F, Than KD, Lin CY (2015) BMP-2 inhibits tumor-initiating ability in human renal cancer stem cells and induces bone formation. J Cancer Res Clin Oncol 141: 1013-1024. [Crossref]

Copyright: (C2017 Maioli H. This is an open-access article distributed under the terms of the Creative Commons Attribution License, which permits unrestricted use, distribution, and reproduction in any medium, provided the original author and source are credited. 